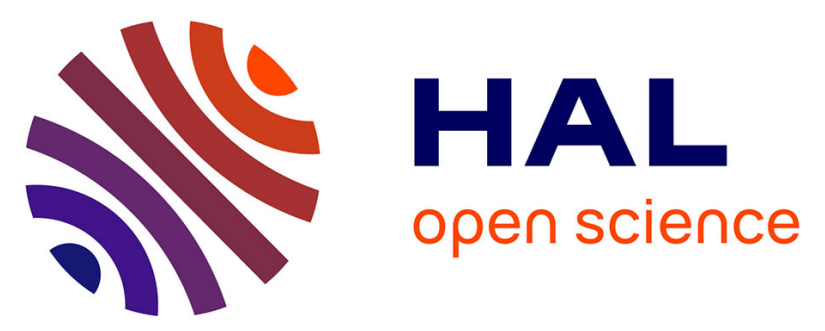

\title{
OSTEOPROTEGERIN INJECTION INDUCES MORPHOLOGICAL AND FUNCTIONAL ALTERATIONS IN MOUSE PANCREATIC ISLETS
}

Barbara Toffoli, Stella Bernardi, Riccardo Candido, Nicoletta Sabato, Renzo

Carretta, Federica Corallini, Paola Secchiero, Giorgio Zauli, Bruno Fabris

\section{To cite this version:}

Barbara Toffoli, Stella Bernardi, Riccardo Candido, Nicoletta Sabato, Renzo Carretta, et al.. OSTEOPROTEGERIN INJECTION INDUCES MORPHOLOGICAL AND FUNCTIONAL ALTERATIONS IN MOUSE PANCREATIC ISLETS. Molecular and Cellular Endocrinology, 2010, 331 (1), pp.136. 10.1016/j.mce.2010.08.019 . hal-00639765

\section{HAL Id: hal-00639765 https://hal.science/hal-00639765}

Submitted on 10 Nov 2011

HAL is a multi-disciplinary open access archive for the deposit and dissemination of scientific research documents, whether they are published or not. The documents may come from teaching and research institutions in France or abroad, or from public or private research centers.
L'archive ouverte pluridisciplinaire HAL, est destinée au dépôt et à la diffusion de documents scientifiques de niveau recherche, publiés ou non, émanant des établissements d'enseignement et de recherche français ou étrangers, des laboratoires publics ou privés. 


\section{Accepted Manuscript}

Title: OSTEOPROTEGERIN INJECTION INDUCES MORPHOLOGICAL AND FUNCTIONAL ALTERATIONS IN MOUSE PANCREATIC ISLETS

Authors: Barbara Toffoli, Stella Bernardi, Riccardo Candido, Nicoletta Sabato, Renzo Carretta, Federica Corallini, Paola

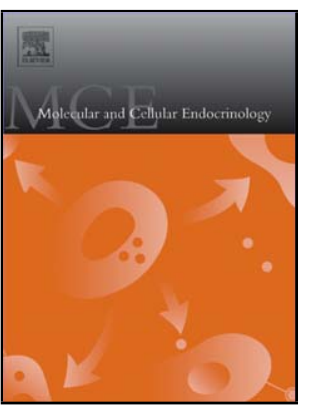

Secchiero, Giorgio Zauli, Bruno Fabris

PII:

S0303-7207(10)00443-0

DOI: doi:10.1016/j.mce.2010.08.019

Reference: MCE 7631

To appear in: $\quad$ Molecular and Cellular Endocrinology

Received date: $\quad 16-7-2010$

Revised date: $\quad 23-8-2010$

Accepted date: $\quad 31-8-2010$

Please cite this article as: Toffoli, B., Bernardi, S., Candido, R., Sabato, N., Carretta, R., Corallini, F., Secchiero, P., Zauli, G., Fabris, B., OSTEOPROTEGERIN INJECTION INDUCES MORPHOLOGICAL AND FUNCTIONAL ALTERATIONS IN MOUSE PANCREATIC ISLETS, Molecular and Cellular Endocrinology (2010), doi:10.1016/j.mce.2010.08.019

This is a PDF file of an unedited manuscript that has been accepted for publication. As a service to our customers we are providing this early version of the manuscript. The manuscript will undergo copyediting, typesetting, and review of the resulting proof before it is published in its final form. Please note that during the production process errors may be discovered which could affect the content, and all legal disclaimers that apply to the journal pertain. 


\section{OSTEOPROTEGERIN INJECTION INDUCES MORPHOLOGICAL AND FUNCTIONAL} ALTERATIONS IN MOUSE PANCREATIC ISLETS

$\underline{\text { Barbara Toffoli }}{ }^{\mathrm{a}}$, Stella Bernardi ${ }^{\mathrm{b}}$, Riccardo Candido ${ }^{\mathrm{c}}$, Nicoletta Sabato ${ }^{\mathrm{b}}$, Renzo Carretta ${ }^{\mathrm{b}}$, Federica Corallini $^{\text {a }}$, Paola Secchiero ${ }^{\text {a }}$, Giorgio Zauli ${ }^{\mathrm{d}}$, $\underline{\text { Bruno Fabris }}$ b,*

${ }^{\mathrm{a}}$ Department of Morphology and Embriology, University of Ferrara, via Fossato di Mortara 64/b, 44100 Ferrara, Italy

${ }^{\mathrm{b}}$ Department of Medical, Technological and Translational Sciences, University of Trieste, Cattinara Hospital, Strada di Fiume 447, 34149 Trieste, Italy

${ }^{c}$ Diabetic Center, District 3, A.S.S.1 Triestina, via Puccini 48/50, 34148 Trieste, Italy

${ }^{\mathrm{d}}$ Institute for Maternal and Child Health, IRCCS Burlo Garofolo, via dell'Istria 65/1, 34137 Trieste, $\underline{\text { Italy }}$

*Corresponding author: Prof. Bruno Fabris, MD, University of Trieste, Department of Medical, Technological and Translational Sciences, c/o Ospedale di Cattinara, Strada di Fiume 447, 34149 Trieste (Italy); Tel: +39 040 910946; Fax: +39 040 912881; E-mail:b.fabris@ fmc.units.it 


\begin{abstract}
Although serum osteoprotegerin (OPG) is significantly increased in diabetic subjects, its potential role in beta cell dysfunction has not been investigated. This study aimed to assess the effect of full length OPG administered in vivo in mice on pancreatic islet structure and function and its interaction with the renin-angiotensin system (RAS).

OPG-treated mice showed increased islet monocyte/macrophage infiltration, fibrosis and apoptosis with reduction of islet function. The remodeling of islet architecture was associated with increased pancreatic expression of components of the RAS, growth factor genes (transforming growth factor $\beta$ and connective tissue growth factor) and inflammatory molecules (monocyte chemotactic protein1 and vascular adhesion molecule type 1). Prevention of these changes with improvement of insulin secretion was observed in ramipril treated animals.

Our data suggest that OPG might play an important role in promoting beta cell dysfunction and that the upregulation of the local RAS represents one possible mechanism responsible for the OPGinduced beta cell dysfunction.
\end{abstract}

Keywords Osteoprotegerin, diabetes, renin-angiotensin system, angiotensin converting enzyme inhibitor. 
Abbreviations

AT1 receptor

AUC

CTGF

MCP-1

OPG

RANKL

RAS

TGF- $\beta$

TRAIL

VCAM-1
Angiotensin II type 1 receptor

Area under insulin curve

Connective tissue growth factor

Monocyte chemotactic protein 1

Osteoprotegerin

Receptor activator of nuclear factor $\mathrm{kB}$ ligand

Renin-angiotensin system

Transforming growth factor $\beta$

TNF-related apoptosis-inducing ligand

Vascular adhesion molecule type 1 


\section{Introduction}

Diabetes mellitus occurs under different clinical forms, however the loss of beta cell mass is recognised as a causal and committed stage in the development of both type 1 and type 2 diabetes (Donath and Halban, 2004). Osteoprotegerin (OPG) is a soluble glycoprotein of the tumor necrosis factor (TNF) receptor superfamily, which was initially identified as a key regulator in bone turnover (Simonet et al., 1997). It acts as a decoy receptor for the receptor activator of nuclear factor $\mathrm{kB}$ ligand (RANKL), a cytokine with strong osteoclast-inducing activity (Boyle et al., 2003). Moreover, there is additional evidence that OPG can promote cell survival by binding to the TNFrelated apoptosis-inducing ligand (TRAIL) (Emery et al., 1998). OPG is mainly secreted by bone but it is also produced by a wide range of tissues including endothelial and smooth muscle cells (Malyankar et al., 2000; Zhang et al., 2002). In the general population, OPG is an independent risk factor for the progression of atherosclerosis and onset of cardiovascular disease (Kiechl et al., 2004; Ueland et al., 2005). Moreover, in patients with coronary artery disease OPG is associated with the severity of coronary atherosclerosis and mortality (Jono et al., 2002; Lieb et al., 2010; Schoppet et al., 2003; Ueland et al., 2004). Interestingly, different groups of investigators have reported that serum OPG levels are significantly increased in both type 1 and type 2 diabetic patients (Browner et al., 2001; Galluzzi et al., 2005; Knudsen et al., 2003; Rasmussen et al., 2006; Secchiero et al., 2006) and in more recent studies performed in diabetic subjects a strong association between plasma levels of OPG and micro- and macroangiopathy was observed (Avignon et al., 2005; Grauslund et al., 2010; Knudsen et al., 2003; Xiang et al., 2009).

However, in spite of the reported findings, the physiopathological role of elevated levels of OPG in pancreatic islet function is not known. The recent demonstration that OPG is expressed in the pancreas and that it can act as a cytokine induced gene in beta cells (Schrader et al., 2007) suggests a potential role for OPG in endocrine pancreatic function. Therefore, the aim of this tudy was to investigate whether OPG is involved in pathogenetic aspects of diabetes mellitus. For this purpose, we studied the effect of full-length OPG administered in vivo in mice on the structure and 
function of pancreatic beta cells. In addition, there is evidence for an interplay between OPG and the renin-angiotensin system (RAS) pathways in human aortas, where OPG has been shown to modulate angiotensin II type 1 (AT1) receptor gene expression (Moran et al., 2009) and, in turn, angiotensin II promotes OPG production (Zhang et al., 2002). Since in our preliminary results the expression of angiotensin converting enzyme (ACE) in the pancreas was markedly increased after chronic OPG administration, we specifically sought to determine whether long term ACE-inhibitor treatment could hinder the effect of exogenous OPG on beta cells remodeling and function. 


\section{Material and methods}

\subsection{Animals and experimental protocol}

Animal care and treatments were conducted in conformity with institutional guidelines in compliance with national and international laws and policies for the care and use of laboratory animals. 40 male mice C57BL/6J, aged 10 weeks, were randomized into 4 groups and studied for 12 weeks. Group 1 received every 3 weeks an i.p. injection of vehicle and served as a control. Group 2 received every 3 weeks an i.p. injection of human recombinant OPG (R\&D Systems, Minneapolis, MN), (1 $\mu \mathrm{g} / \mathrm{mouse}$ in a total of $200 \mu \mathrm{l}$ HEPES-buffered saline) (Candido et al., 2010). Group 3 received the ACE inhibitor ramipril (Sigma Aldrich, St. Louis, MO, USA) at the dose of $10 \mathrm{mg} / \mathrm{kg} / \mathrm{die}$ in drinking water in co-treatment with i.p. injections of vehicle. Group 4 received ramipril in co-treatment with i.p. injections of OPG. The animals were maintained on regular mouse chow. Ramipril was added to the drinking water, stored at $4^{\circ} \mathrm{C}$ and replaced twice a week. Previous studies had demonstrated that ramipril remains stable in water for more than four days at room temperature and that the dosage used in mice is well below the toxic range and equivalent to the maximum therapeutic dose of $10 \mathrm{mg}$ per day in humans (Gross et al., 2003). Adjustment of drug concentration according to the fluid intake ensured that the daily dose was applied during the whole experiment. In addition, we have previously shown the effectiveness of an oral chronic delivery of ACE inhibitor (Candido et al., 2002).

\subsection{Measurement of physiological and biochemical parameters}

At 4-week intervals, the following parameters were measured in all groups: body weight; systolic blood pressure measured by tail-cuff plethysmography in conscious, prewarmed mice; fasting glucose levels using a glucose oxidase method (Menarini, Florence, Italy); and fasting insulin serum levels. After 3 months, animals were anesthetized by an i.p. injection of pentobarbital sodium (60 mg/kg body weight). Blood was collected from the left ventricle and centrifuged and plasma was stored at $-20^{\circ} \mathrm{C}$ for subsequent analysis. The mouse pancreas was rapidly dissected out 
and bisected longitudinally, with one half snap frozen in liquid nitrogen and stored at $-80^{\circ} \mathrm{C}$ for subsequent quantitative RT-PCR measurements, and the other half fixed in $4 \%$ paraformaldehyde and embedded in paraffin for immunohistochemical studies.

\subsection{Oral glucose tolerance test}

An oral glucose tolerance test was performed at the end of the experimental study. For this purpose, conscious mice, overnight fasted, received an oral glucose bolus ( $1 \mathrm{~g} / \mathrm{Kg}$ body weight) by gavage and blood was collected from the tail vein at 0, 30, 90 and 120 minutes $\underline{(\mathrm{Chu} \text { et al., 2006)}}$. Serum insulin levels were determined by using the Mouse Insulin ultrasensitive ELISA kit (DRG International, Inc., USA).

\subsection{Picrosirius red staining}

Sirius red polarization microscopy was used to detect interstitial collagen. Four-micron paraffin sections were prepared from $4 \%$ paraformaldeyde-fixed, paraffin-embedded mice pancreas. Sections were stained with $0.1 \%$ Sirius red (Direct red 80; Fluka Chemika, St Louis, MO, USA) in satured picric acid (picrosirius red) for 90 minutes and mounted.

\subsection{Immunohistochemistry}

The expression of the beta cell marker insulin, ACE and AT1 receptor were examined by immunohistochemistry on four-micron paraffin pancreas sections. The primary antibodies used were a polyclonal guinea pig anti-swine insulin antibody (1:100; DAKO, Glostrup, Denmark), a monoclonal mouse anti-human ACE antibody (1:100; Chemicon, Temecula, CA, USA), and a polyclonal rabbit anti-human AT1 receptor antibody (1:200; Santa Cruz Biotechnology, Inc, Santa Cruz, California). After neutralization of endogenous peroxidase, the sections were incubated with the primary antibodies for 1 hour at room temperature for ACE and AT1 receptor or overnight at $4^{\circ} \mathrm{C}$ for insulin. After washing, biotinylated secondary antibodies (all from Vector Laboratories, 
Burlingame, CA) were applied for 60 minutes for ACE and AT1 receptor or 30 minutes for insulin. Specific immunohistochemical staining was detected using the standard avidin-biotin complex (Vector Laboratories) method. After an extensive washing, the final detection step was carried out using 3,3'-diaminobenzidine tetrahydrochloride (Sigma Chemical, St Louis, MO, USA) as the chromogen.

Detection of cells of the monocytic/macrophagic lineage was performed by using the primary antibody for F4/80 (1:200; AbD Serotec, Oxford, UK), followed by secondary anti-rat immunoglobulins (1:200; Vector Laboratories) and the CSA mouse amplification kit (DAKO, Glostrup, Denmark), following manufacturer's instructions.

After counterstaining with hematoxylin, all the sections were examined by light microscopy (Olympus BX50WI, Hamburg, Germany) and digitized with a high resolution camera (Q-Imaging Fast 1394, Surrey, BC, Canada). Semiquantitative assessment of islet proteins was performed by determining the percentage proportion of area or number of cells per islet section occupied by the brown (DAB) staining within each islet (20X objective) using an image analysis system (Image Pro Plus ${ }^{\circledR}$ 6.3 Software, Media-Cybernetics, Silver Spring, MD, USA). A total of 40-50 islets per mouse pancreas ( $\mathrm{n}=10$ mice/group) were analyzed.

Pancreatic beta cell mass was estimated by multiplying the mean density of staining for insulin in the islet section by the mean islet area per area of pancreas. This was expressed in arbitrary units adjusted for the pancreatic wet weight for individual animals (Tikellis et al., 2004).

\subsection{In situ detection of apoptosis}

The localization of beta cell apoptosis was identified using dual immunofluorescence for Terminal Deoxynucleotidyl Transferase-Mediated dUTP Nick End Labeling (TUNEL) and insulin staining. After digestion with Proteinase K (20 $\mu \mathrm{g} / \mathrm{ml}$; Sigma Chemical), four micron paraffin sections were labeled with polyclonal guinea pig anti swine insulin (1:100; DAKO), followed by a Texas Red dye-conjugated secondary antibody (1:100; Vector Laboratories). Slides were 
subsequently labeled for TUNEL-positive cells and visualized using fluorescein dye according to the manufacturer's instructions (Roche Diagnostic, Indianapolis, IN, USA). TUNEL-positive beta cells were identified by the presence of green nuclei and red cytoplasm.

\subsection{Real-Time quantitative PCR}

Total RNA was isolated from snap-frozen pancreatic tissue after homogenisation in Trizol (Invitrogen, Milan, Italy). A reverse transcriptase reaction was performed on three micrograms of RNA using random hexamers, dNTPs and M-MLV reverse transcriptase (Invitrogen).

Angiotensin converting enzyme (ACE), angiotensin II type 1 (AT1) receptor, monocyte chemotactic protein (MCP-1), vascular adhesion molecule type 1 (VCAM-1), transforming growth factor $\beta$ (TGF- $\beta$ ) and connective tissue growth factor (CTGF) gene expression were analyzed by real-time quantitative RT-PCR using the TaqMan system based on real time detection of accumulated fluorescence (ABI Prism 7900HT, Foster City, CA, USA). To control for variation in the amount of cDNA available for PCR in the different samples, gene expression of the target sequence was normalized in relation to the expression of an endogenous control, $18 \mathrm{~S}$ ribosomal RNA (rRNA) (18S rRNA TaqMan Control Reagent kit; Applied Biosystem). Specific primers and Taqman probes for ACE, AT1 receptor, MCP-1, VCAM-1, TGF- $\beta$ and CTGF (Table 1) were constructed with the help of Primer Express (PE Applied Biosystem). Each sample was tested in triplicate. Results were expressed relative to control pancreas values, which were arbitrarily assigned a value of 1 .

\subsection{Statistical analysis}

Analysis of variance (ANOVA), calculated using Statview 512 software for Apple Macintosh computer (Brainpower, Calabasas, California, USA), was used to determine the presence of significant difference between groups. Comparisons of group means were performed by Fisher's 
least significant difference (LSD) method unless otherwise specified. Results are expressed as mean \pm SEM. A $P$ value of less than 0.05 was considered statistically significant. 


\section{Results}

\subsection{Body weight and systolic blood pressure}

No difference between body weight and baseline systolic blood pressure was determined in animals prior to randomization. The body weight and systolic blood pressure were not significantly different in animals injected or not with human recombinant OPG (Table 2). Treatment with ACE inhibitor ramipril did not influence body weight. A significant reduction in systolic blood pressure was observed in animals treated with ramipril. Moreover no gross skeletal alterations at necroscopic examination in OPG-treated animals with respect to vehicle- or ramipril treated mice was observed.

\subsection{Glicemic control and insulinemia}

Fasting blood glucose levels were measured every 4 weeks for 3 months using a glucose oxidase method. Mice injected with recombinant human OPG had significantly higher blood glucose levels after 2 and 3 months of treatment compared to control mice $(P<0.05)$. Treatment with ramipril completely prevented the glicemic increase induced by OPG administration $(P<0.05)$

(Figure 1, panel A). Consistently with the situation of fasting hyperglycemia, OPG-treated mice exhibited a reduction in serum insulin with respect to the CONT animals, that was statistically significant after 3 months of treatment $(P<0.05)$. In the same way, co-treatment with the ACE inhibitor significantly improved insulin secretion in OPG injected mice $(P<0.05)$ (Figure 1, panel B). Similarly the area under the insulin curve (AUC), evaluated between 0 and 120 minutes after the glucose challenge, was significantly reduced in OPG-treated mice compared to control animals $(P<0.01)$. The co-treatment with ramipril induced a statistically significant improve in the AUC of the OPG injected mice $(P<0.01)$. Treatment with ramipril alone didn't alter the AUC with respect to untreated mice (Table 2).

\subsection{Insulin and beta cell mass}


Immunohistochemical staining for beta cell marker insulin was strong and intense in control mice islets. In contrast, mice injected with recombinant human OPG presented islets that showed an attenuated and variable pattern of staining suggestive of progressive beta cell loss (Figure 2). Consistent with these evidences, the mean percentage of proportional area staining positively for insulin in the OPG treated mice was significantly reduced with respect to CONT mice (CONT 47.1 \pm 1.3 ; OPG $39.6 \pm 1.4 ; P<0.0001)$. Treatment with ramipril significantly increased the staining density for insulin (OPG-R $50.7 \pm 1.5$; vs OPG $P<0.0001)$. No difference in insulin pattern was observed in mice treated with ramipril alone compared to control mice islets (CONT-R 49.6 \pm 1.3 ).

Pancreatic beta cell mass was estimated by multiplying the mean islet density of staining for insulin by the mean islet area per area of pancreas. This was expressed in arbitrary units adjusted for the pancreatic wet weight for individual animals. OPG treated mice had a marked reduction in beta cell mass with respect to the mice injected with vehicle (CONT $14.8 \pm 1.6$; OPG 9.56 \pm 0.9 ; $P<0.05$ ). Blockade of the RAS further increased total pancreas insulin content (OPG-R $14.2 \pm 1.6$ vs OPG $P<0.05)$. Treatment with ramipril alone had no effect on the total beta cell mass $(\mathrm{CONT}-\mathrm{R}$ $13.9 \pm 1.5)$

\subsection{Islet architecture and fibrosis}

Islets in OPG treated animals were significantly enlarged with disarray of islet architecture, and irregular islet boundaries. Treatment with ramipril largely attenuated these changes (Figure 2). The in vivo administration of human OPG increased significantly Picrosirius staining both within and at the boundary of the islets $(P<0.05)$ and this increase was completely prevented by ramipril treatment. Ramipril alone didn't alter the total collagen content of the islets compared to the control animals (Table 3).

\subsection{Islet cell apoptosis}


TUNEL staining was used to identify apoptotic cells within islet boundaries. Intraislet cell death was significantly greater in OPG injected mice (7-fold) compared with infrequent apoptotic cells seen in control islets $(P<0.01)$. Blockade of the RAS with ramipril reduced TUNEL staining within islet cells to control levels (Figure 3).

\subsection{Infiltration of cells of the monocytic/macrophagic lineage}

To investigate whether OPG treatment affected the degree of infiltration of cells of the monocytic/macrophagic lineage, serial sections of paraffin-embedded pancreas were stained for F4/80 antigen (Figure 2). Peri-insular and intra-insular infiltrations were significantly $(P<0.05)$ increased in OPG-injected mice (2- and 3.7 fold, respectively) when compared with control animals injected with vehicle. Co-treatment with lifelong ramipril significantly reduced the expression of F4/80 protein in islets (Table 3).

\subsection{MCP-1, VCAM-1, TGF- $\beta$ and CTGF expression}

To quantify mRNA levels of the inflammatory and prosclerotic cytokines reverse transcription polymerase chain reaction was performed in whole pancreas extracts. The injections with recombinant human OPG promoted a significant increase in MCP-1, VCAM-1, TGF- $\beta$ and CTGF gene expression (Figure 4). These increases were completely prevented by the treatment with the ACE inhibitor ramipril (Figure 4).

\subsection{ACE and ATl receptor gene and protein expression}

OPG-treated mice showed an activation of the local RAS as assessed by a significant increase in ACE and AT1 receptor gene expression (by 8.7- and 2.2 fold, respectively) in the pancreas when compared with control animals (Table 4). Densitometric analysis of pancreatic ACE and AT1 receptor demonstrated the same pattern as seen with respect to ACE and AT1 gene expression. Ramipril treatment prevented the up-regulation of ACE and AT1 receptor compared to 
treated OPG animals with mRNA and proteins levels similar to that observed in control animals (Table 4). 


\section{Discussion}

In the present study we have demonstrated for the first time that the systemic administration of recombinant OPG promotes significant histopathological changes in pancreatic islets including selective loss of beta cells by apoptosis, increased infiltration of monocytes/macrophages, increased expression of inflammatory molecules and fibrosis. In addition, exogenous administration of OPG also induced a significant increase of gene and protein expression of the ACE and AT1 receptor and we have also observed the attenuation of these changes after chronic blockade of the RAS, in keeping with previous strong evidence that most of the components of functioning RAS are present locally in the endocrine pancreas and that islet RAS has a role in regulating pancreatic islet function (Leung and Carlsson, 2001; Tikellis et al., 2006). These findings are particularly relevant since it has been shown that angiotensin II plays an important role in regulating insulin islet secretion (Carlsson et al., 1998; Lau et al., 2004) and the process that leads to beta cell loss and dysfunction in type 1 and type 2 diabetes is significantly influenced by local activation of the RAS (Tikellis et al., 2006).

The molecular mechanism by which OPG controls ACE and AT1 gene expression is not known. The expression of ACE and AT1 receptor have been shown to be associated with activation of the mitogen-activated protein kinase (MAPK) and nuclear factor-kB transduction pathways (Cowling et al., 2002; Koka et al., 2008; Martin et al., 2007). In this respect, it should be emphasized that OPG is able to stimulate MAPK signaling (Theoleyre et al., 2004). Taking these data together with the present study it prompts us to hypothesize that OPG might control transcription mechanism governing ACE and AT1 gene expression. In this respect, it should also be taken into account that pancreatic inflammation may also result in the upregulation of local RAS as demonstrated in animal models of pancreatitis (Kuno et al., 2003). A possible pathogenetic link between elevated levels of OPG and inflammation has been suggested by recent in vitro studies by our group (Zauli et al., 2007) and that of Mangan et al (2007) demonstrating that exposure to recombinant OPG promotes leukocyte adhesion to endothelial cells. In our experimental setting, an 
islet accumulation of cells of the monocytic/macrophagic lineage was noted after OPG administration. This was associated with an increase expression of $\mathrm{MCP}-1$, a proinflammatory chemoattractant whose expression correlates with the progression of insulitis and beta cell destruction in NOD mice (Chen et al., 2001). Recently, an increase mRNA for MCP-1 was found in islet from GK rat, a spontaneous model of type II diabetes (Ehses et al., 2009). In addition, the endothelial adhesion molecule VCAM-1, which is important for the adhesion of macrophages to the vascular wall, as demonstrated in experimental diabetes (Candido et al., 2004), was also significantly increased in OPG-treated animals. Previous studies have demonstrated that the proinflammatory effect of OPG is mediated by a direct interactivity with cell surface heparan solfate (Mosheimer et al., 2005) or alternatively by preventing the antiinflammatory activity of TRAIL (Zauli et al., 2009). In this respect, it is particularly noteworthy that the TRAIL death pathway is present in islet beta cells (Ou et al., 2002) and we have recently demonstrated that recombinant TRAIL ameliorates the severity of streptozotocin-induced type 1 diabetes (Zauli et al., 2010). Therefore, a possible mechanism by which OPG might contribute to beta cell dysfunction is by inhibiting the antiinflammatory activity of circulating TRAIL. Notwithstanding these multiple potential pathways mediating the inflammatory response to OPG, all the inflammatory effects observed in our study after administration of OPG may be explained by the local RAS upregulation and its downstream sequelae. In accordance with this hypothesis, ACE inhibitor treatment prevented all the OPG-induced inflammatory changes.

In native tissues, the interaction between pancreatic beta cells and elements of their local micro-environment including extracellular matrix is essential to activate intracellular signaling pathways that regulate cell proliferation, survival and function. Loss of cell-to-cell communications associated with increased intraislet fibrosis may reduce the secretory efficiency of the islet and promote islet cell apoptosis (Tikellis et al., 2004). We report here that chronic OPG treatment increases peri- and intrainsula fibrosis and promotes the expression of TGF- $\beta$ mRNA and its downstream effector CTGF in the pancreas. Both TGF- $\beta$ and CTGF have been associated with 
fibrosis in diabetic nephropathy (Murphy et al., 1999) and pancreatitis (di Mola et al., 1999; Kuno et al., 2003). Furthermore, Tikellis and coll. have previously reported that diabetes mellitus is associated with increased expression of TGF- $\beta$ and CTGF in the islet of ZDF rats (Tikellis et al., 2004). Also the RAS has been linked to increased fibrosis in a variety of tissues including the heart (Seccia et al., 2003), kidney (Satoh et al., 2001) and liver (Yoshiji et al., 2001). In fact, locally produced angiotensin II is thought to upregulate, via AT1 receptor, the expression of fibrogenic cytokines and growth factors including TGF- $\beta$ and CTGF (Ruperez et al., 2003). Moreover, the use of an ACE inhibitor or AT1 receptor antagonist have been shown to result in reduced fibrosis from inhibtion of TGF- $\beta$ and CTGF in animal models of diabetes mellitus (Tikellis et al., 2004) and pancreatitis (Kuno et al., 2003). It is conceivable that the reduction in islet fibrosis observed in this study after treatment with ramipril may be mediated through a similar pathway.

Pancreatic beta cell death by apoptosis is believed to be the primary mechanism for the reduction of beta cell mass and volume in both type 1 and type 2 diabetes (Thomas et al., 2009). Apoptosis in beta cell is a highly complex process and angiotensin II has been shown to play a relevant role in the control of beta cell life and death (Yuan et al., 2010). In the present study the OPG induction of islet apoptosis is closely related to upregulation of pancreatic RAS and these changes were prevented after treatment with ramipril.

A limitation of the present study relates to the use of whole pancreas extract for gene studies while it is well known that measurement of mRNA levels in isolated islets would be more informative and accurate. Nevertheless this limitation does not influence our basic finding of a strict association of the OPG-induced beta cell dysfunction with increased pancreatic expression of component of the RAS.

The maintenance of beta cell area/density is important for maintaining a correct insulin secretion. Consistently with a protective role of ramipril the levels of insulinemia were significantly higher in mice treated with OPG + ramipril, and OPG + ramipril treated animals showed reduced level of hyperglycemia throughout the whole period of the study with respect to OPG-injected 
animals. Moreover ramipril co-treatment significantly ameliorated insulin response after the glucose challenge, suggesting an improvement in beta cell function. Because disruption of contacts between beta cells and beta cell loss reduces the secretory efficiency of islets, the results illustrated in our study suggest a potential mechanism to explain why pathologically elevated serum OPG levels, frequently occurring in both type 1 and type 2 diabetes (Browner et al., 2001; Galluzzi et al., 2005; Knudsen et al., 2003; Rasmussen et al., 2006; Secchiero et al., 2006), are linked to the development and/or maintenance of diabetes mellitus.

Previous studies have demonstrated a pro-atherosclerotic role for OPG in the vasculature which may be particularly prominent in diabetes mellitus (Candido et al., 2010; Knudsen et al., 2003; Rasmussen et al., 2006). Moreover it has been shown that OPG is an NF-kB-inducible gene, whose expression and release in culture of vascular cells is significantly increased by inflammatory cytokines (Collin-Osdoby et al., 2001). Although it cannot be ruled out that high plasma OPG levels are an epiphenomenon of inflammatory processes harbored in vascular lesions, our present data $\underline{\text { suggest rather that elevated level of OPG in diabetes may have an active role in pancreatic islet }}$ pathophysiology. 


\section{Conclusion}

The present study indicates in the overactivity of the local RAS one of the possible mechanisms responsible for the OPG-induced islet beta cell dysfunction, and this may explain why the use of an ACE inhibitor may be suitable to target OPG pancreatic effect. Further studies are necessary to fully elucidate the potential relevance of OPG in the development of beta cell failure and provide the rationale to consider this cytokine as a target for new approaches to retard the development of diabetes. 


\section{References}

Avignon, A., Sultan, A., Piot, C., Elaerts, S., Cristol, J.P. , Dupuy, A.M., 2005. Osteoprotegerin is associated with silent coronary artery disease in high-risk but asymptomatic type 2 diabetic patients. Diabetes Care. 28, 2176-80.

Boyle, W.J., Simonet, W.S. , Lacey, D.L., 2003. Osteoclast differentiation and activation. Nature. 423, 337-42.

Browner, W.S., Lui, L.Y. , Cummings, S.R., 2001. Associations of serum osteoprotegerin levels with diabetes, stroke, bone density, fractures, and mortality in elderly women. J Clin Endocrinol Metab. 86, 631-7.

Candido, R., Allen, T.J., Lassila, M., Cao, Z., Thallas, V., Cooper, M.E. , Jandeleit-Dahm, K.A., 2004. Irbesartan but not amlodipine suppresses diabetes-associated atherosclerosis. Circulation. 109, 1536-42.

Candido, R., Jandeleit-Dahm, K.A., Cao, Z., Nesteroff, S.P., Burns, W.C., Twigg, S.M., Dilley, R.J., Cooper, M.E. , Allen, T.J., 2002. Prevention of accelerated atherosclerosis by angiotensin-converting enzyme inhibition in diabetic apolipoprotein E-deficient mice. Circulation. 106, 246-53.

Candido, R., Toffoli, B., Corallini, F., Bernardi, S., Zella, D., Voltan, R., Grill, V., Celeghini, C. , Fabris, B., 2010. Human full-length osteoprotegerin induces the proliferation of rodent vascular smooth muscle cells both in vitro and in vivo. J Vasc Res. 47, 252-61.

Carlsson, P.O., Berne, C. , Jansson, L., 1998. Angiotensin II and the endocrine pancreas: effects on islet blood flow and insulin secretion in rats. Diabetologia. 41, 127-33.

Chen, M.C., Proost, P., Gysemans, C., Mathieu, C. , Eizirik, D.L., 2001. Monocyte chemoattractant protein-1 is expressed in pancreatic islets from prediabetic NOD mice and in interleukin-1 beta-exposed human and rat islet cells. Diabetologia. 44, 325-32.

Chu, K.Y., Lau, T., Carlsson, P.O. , Leung, P.S., 2006. Angiotensin II type 1 receptor blockade improves beta-cell function and glucose tolerance in a mouse model of type 2 diabetes. Diabetes. 55, 367-74.

Collin-Osdoby, P., Rothe, L., Anderson, F., Nelson, M., Maloney, W. , Osdoby, P., 2001. Receptor activator of NF-kappa B and osteoprotegerin expression by human microvascular endothelial cells, regulation by inflammatory cytokines, and role in human osteoclastogenesis. J Biol Chem. 276, 20659-72.

Cowling, R.T., Gurantz, D., Peng, J., Dillmann, W.H. , Greenberg, B.H., 2002. Transcription factor NF-kappa B is necessary for up-regulation of type 1 angiotensin II receptor mRNA in rat cardiac fibroblasts treated with tumor necrosis factor-alpha or interleukin-1 beta. J Biol Chem. 277, 5719-24.

di Mola, F.F., Friess, H., Martignoni, M.E., Di Sebastiano, P., Zimmermann, A., Innocenti, P., Graber, H., Gold, L.I., Korc, M. , Buchler, M.W., 1999. Connective tissue growth factor is a regulator for fibrosis in human chronic pancreatitis. Ann Surg. 230, 63-71.

Donath, M.Y. , Halban, P.A., 2004. Decreased beta-cell mass in diabetes: significance, mechanisms and therapeutic implications. Diabetologia. 47, 581-9.

Ehses, J.A., Lacraz, G., Giroix, M.H., Schmidlin, F., Coulaud, J., Kassis, N., Irminger, J.C., Kergoat, M., Portha, B., Homo-Delarche, F. , Donath, M.Y., 2009. IL-1 antagonism reduces hyperglycemia and tissue inflammation in the type 2 diabetic GK rat. Proc Natl Acad Sci U SA. 106, 13998-4003.

Emery, J.G., McDonnell, P., Burke, M.B., Deen, K.C., Lyn, S., Silverman, C., Dul, E., Appelbaum, E.R., Eichman, C., DiPrinzio, R., Dodds, R.A., James, I.E., Rosenberg, M., Lee, J.C. , Young, P.R., 1998. Osteoprotegerin is a receptor for the cytotoxic ligand TRAIL. J Biol Chem. 273, 14363-7. 
Galluzzi, F., Stagi, S., Salti, R., Toni, S., Piscitelli, E., Simonini, G., Falcini, F. , Chiarelli, F., 2005. Osteoprotegerin serum levels in children with type 1 diabetes: a potential modulating role in bone status. Eur J Endocrinol. 153, 879-85.

Grauslund, J., Rasmussen, L.M., Green, A. , Sjolie, A.K., 2010. Does osteoprotegerin relate to micro- and macrovascular complications in long-term type 1 diabetes? Scand J Clin Lab Invest. 70, 188-93.

Gross, O., Beirowski, B., Koepke, M.L., Kuck, J., Reiner, M., Addicks, K., Smyth, N., SchulzeLohoff, E. , Weber, M., 2003. Preemptive ramipril therapy delays renal failure and reduces renal fibrosis in COL4A3-knockout mice with Alport syndrome. Kidney Int. 63, 438-46.

Jono, S., Ikari, Y., Shioi, A., Mori, K., Miki, T., Hara, K. , Nishizawa, Y., 2002. Serum osteoprotegerin levels are associated with the presence and severity of coronary artery disease. Circulation. 106, 1192-4.

Kiechl, S., Schett, G., Wenning, G., Redlich, K., Oberhollenzer, M., Mayr, A., Santer, P., Smolen, J., Poewe, W. , Willeit, J., 2004. Osteoprotegerin is a risk factor for progressive atherosclerosis and cardiovascular disease. Circulation. 109, 2175-80.

Knudsen, S.T., Foss, C.H., Poulsen, P.L., Andersen, N.H., Mogensen, C.E. , Rasmussen, L.M., 2003. Increased plasma concentrations of osteoprotegerin in type 2 diabetic patients with microvascular complications. Eur J Endocrinol. 149, 39-42.

Koka, V., Huang, X.R., Chung, A.C., Wang, W., Truong, L.D. , Lan, H.Y., 2008. Angiotensin II upregulates angiotensin I-converting enzyme (ACE), but down-regulates ACE2 via the AT1-ERK/ p38 MAP kinase pathway. Am J Pathol. 172, 1174-83.

Kuno, A., Yamada, T., Masuda, K., Ogawa, K., Sogawa, M., Nakamura, S., Nakazawa, T., Ohara, H., Nomura, T., Joh, T., Shirai, T. , Itoh, M., 2003. Angiotensin-converting enzyme inhibitor attenuates pancreatic inflammation and fibrosis in male Wistar Bonn/ Kobori rats. Gastroenterology. 124, 1010-9.

Lau, T., Carlsson, P.O. , Leung, P.S., 2004. Evidence for a local angiotensin-generating system and dose-dependent inhibition of glucose-stimulated insulin release by angiotensin II in isolated pancreatic islets. Diabetologia. 47, 240-8.

Leung, P.S. , Carlsson, P.O., 2001. Tissue renin-angiotensin system: its expression, localization, regulation and potential role in the pancreas. J Mol Endocrinol. 26, 155-64.

Lieb, W., Gona, P., Larson, M.G., Massaro, J.M., Lipinska, I., Keaney, J.F., Jr., Rong, J., Corey, D., Hoffmann, U., Fox, C.S., Vasan, R.S., Benjamin, E.J., O'Donnell, C.J. , Kathiresan, S., 2010. Biomarkers of the Osteoprotegerin Pathway. Clinical Correlates, Subclinical Disease, Incident Cardiovascular Disease, and Mortality. Arterioscler Thromb Vasc Biol.

Malyankar, U.M., Scatena, M., Suchland, K.L., Yun, T.J., Clark, E.A. , Giachelli, C.M., 2000. Osteoprotegerin is an alpha vbeta 3-induced, NF-kappa B-dependent survival factor for endothelial cells. J Biol Chem. 275, 20959-62.

Mangan, S.H., Van Campenhout, A., Rush, C. , Golledge, J., 2007. Osteoprotegerin upregulates endothelial cell adhesion molecule response to tumor necrosis factor-alpha associated with induction of angiopoietin-2. Cardiovasc Res. 76, 494-505.

Martin, M.M., Buckenberger, J.A., Jiang, J., Malana, G.E., Knoell, D.L., Feldman, D.S. , Elton, T.S., 2007. TGF-beta1 stimulates human AT1 receptor expression in lung fibroblasts by cross talk between the Smad, p38 MAPK, JNK, and PI3K signaling pathways. Am J Physiol Lung Cell Mol Physiol. 293, L790-9.

Moran, C.S., Cullen, B., Campbell, J.H. , Golledge, J., 2009. Interaction between angiotensin II, osteoprotegerin, and peroxisome proliferator-activated receptor-gamma in abdominal aortic aneurysm. J Vasc Res. 46, 209-17.

Mosheimer, B.A., Kaneider, N.C., Feistritzer, C., Djanani, A.M., Sturn, D.H., Patsch, J.R. , Wiedermann, C.J., 2005. Syndecan-1 is involved in osteoprotegerin-induced 
chemotaxis in human peripheral blood monocytes. J Clin Endocrinol Metab. 90, 296471.

Murphy, M., Godson, C., Cannon, S., Kato, S., Mackenzie, H.S., Martin, F. , Brady, H.R., 1999. Suppression subtractive hybridization identifies high glucose levels as a stimulus for expression of connective tissue growth factor and other genes in human mesangial cells. J Biol Chem. 274, 5830-4.

Ou, D., Metzger, D.L., Wang, X., Huang, J., Pozzilli, P. , Tingle, A.J., 2002. TNF-related apoptosisinducing ligand death pathway-mediated human beta-cell destruction. Diabetologia. 45, 1678-88.

Rasmussen, L.M., Tarnow, L., Hansen, T.K., Parving, H.H. , Flyvbjerg, A., 2006. Plasma osteoprotegerin levels are associated with glycaemic status, systolic blood pressure, kidney function and cardiovascular morbidity in type 1 diabetic patients. Eur J Endocrinol. 154, 75-81.

Ruperez, M., Ruiz-Ortega, M., Esteban, V., Lorenzo, O., Mezzano, S., Plaza, J.J , Egido, J., 2003. Angiotensin II increases connective tissue growth factor in the kidney. Am J Pathol. $163,1937-47$.

Satoh, M., Kashihara, N., Yamasaki, Y., Maruyama, K., Okamoto, K., Maeshima, Y., Sugiyama, H., Sugaya, T., Murakami, K. , Makino, H., 2001. Renal interstitial fibrosis is reduced in angiotensin II type 1a receptor-deficient mice.J Am Soc Nephrol. 12, 317-25.

Schoppet, M., Sattler, A.M., Schaefer, J.R., Herzum, M., Maisch, B. , Hofbauer, L.C., 2003. Increased osteoprotegerin serum levels in men with coronary artery disease. J Clin Endocrinol Metab. 88, 1024-8.

Schrader, J., Rennekamp, W., Niebergall, U., Schoppet, M., Jahr, H., Brendel, M.D., Horsch, D. , Hofbauer, L.C., 2007. Cytokine-induced osteoprotegerin expression protects pancreatic beta cells through p38 mitogen-activated protein kinase signalling against cell death. Diabetologia. 50, 1243-7.

Secchiero, P., Corallini, F., Pandolfi, A., Consoli, A., Candido, R., Fabris, B., Celeghini, C., Capitani, S. , Zauli, G., 2006. An increased osteoprotegerin serum release characterizes the early onset of diabetes mellitus and may contribute to endothelial cell dysfunction. Am J Pathol. 169, 2236-44.

Seccia, T.M., Belloni, A.S., Kreutz, R., Paul, M., Nussdorfer, G.G., Pessina, A.C. , Rossi, G.P., 2003. Cardiac fibrosis occurs early and involves endothelin and AT-1 receptors in hypertension due to endogenous angiotensin II.J Am Coll Cardiol. 41, 666-73.

Simonet, W.S., Lacey, D.L., Dunstan, C.R., Kelley, M., Chang, M.S., Luthy, R., Nguyen, H.Q., Wooden, S., Bennett, L., Boone, T., Shimamoto, G., DeRose, M., Elliott, R., Colombero, A., Tan, H.L., Trail, G., Sullivan, J., Davy, E., Bucay, N., Renshaw-Gegg, L., Hughes, T.M., Hill, D., Pattison, W., Campbell, P., Sander, S., Van, G., Tarpley, J., Derby, P., Lee, R. , Boyle, W.J., 1997. Osteoprotegerin: a novel secreted protein involved in the regulation of bone density. Cell. 89, 309-19.

Theoleyre, S., Wittrant, Y., Couillaud, S., Vusio, P., Berreur, M., Dunstan, C., Blanchard, F., Redini, F. , Heymann, D., 2004. Cellular activity and signaling induced by osteoprotegerin in osteoclasts: involvement of receptor activator of nuclear factor kappaB ligand and MAPK. Biochim Biophys Acta. 1644, 1-7.

Thomas, H.E., McKenzie, M.D., Angstetra, E., Campbell, P.D. , Kay, T.W., 2009. Beta cell apoptosis in diabetes. Apoptosis. 14, 1389-404.

Tikellis, C., Cooper, M.E. , Thomas, M.C., 2006. Role of the renin-angiotensin system in the endocrine pancreas: implications for the development of diabetes. Int J Biochem Cell Biol. 38, 737-51. 
Tikellis, C., Wookey, P.J., Candido, R., Andrikopoulos, S., Thomas, M.C. , Cooper, M.E., 2004. Improved islet morphology after blockade of the renin- angiotensin system in the ZDF rat. Diabetes. 53, 989-97.

Ueland, T., Jemtland, R., Godang, K., Kjekshus, J., Hognestad, A., Omland, T., Squire, I.B., Gullestad, L., Bollerslev, J., Dickstein, K. , Aukrust, P., 2004. Prognostic value of osteoprotegerin in heart failure after acute myocardial infarction.J Am Coll Cardiol. 44, 1970-6.

Ueland, T., Yndestad, A., Oie, E., Florholmen, G., Halvorsen, B., Froland, S.S., Simonsen, S., Christensen, G., Gullestad, L. , Aukrust, P., 2005. Dysregulated osteoprotegerin/ RANK ligand/ RANK axis in clinical and experimental heart failure. Circulation. 111, 2461-8.

Xiang, G.D., Pu, J.H., Zhao, L.S., Sun, H.L., Hou, J. , Yue, L., 2009. Association between plasma osteoprotegerin concentrations and urinary albumin excretion in Type 2 diabetes. Diabet Med. 26, 397-403.

Yoshiji, H., Kuriyama, S., Yoshii, J., Ikenaka, Y., Noguchi, R., Nakatani, T., Tsujinoue, H. , Fukui, H., 2001. Angiotensin-II type 1 receptor interaction is a major regulator for liver fibrosis development in rats. Hepatology. 34, 745-50.

Yuan, L., Li, X., Xu, G.L. , Qi, C.J., 2010. Effects of renin-angiotensin system blockade on islet function in diabetic rats. J Endocrinol Invest. 33, 13-9.

Zauli, G., Corallini, F., Bossi, F., Fischetti, F., Durigutto, P., Celeghini, C., Tedesco, F. , Secchiero, P., 2007. Osteoprotegerin increases leukocyte adhesion to endothelial cells both in vitro and in vivo. Blood. 110, 536-43.

Zauli, G., Melloni, E., Capitani, S. , Secchiero, P., 2009. Role of full-length osteoprotegerin in tumor cell biology. Cell Mol Life Sci. 66, 841-51.

Zauli, G., Toffoli, B., di Iasio, M.G., Celeghini, C., Fabris, B. , Secchiero, P., 2010. Treatment with recombinant tumor necrosis factor-related apoptosis-inducing ligand alleviates the severity of streptozotocin-induced diabetes. Diabetes. 59, 1261-5.

Zhang, J., Fu, M., Myles, D., Zhu, X., Du, J., Cao, X. , Chen, Y.E., 2002. PDGF induces osteoprotegerin expression in vascular smooth muscle cells by multiple signal pathways. FEBS Lett. 521, 180-4. 


\section{Figure legends}

Fig. 1. Effect of in vivo injections of recombinant OPG on fasting blood glucose and insulin serum levels. Kinetics of blood glucose levels, measured using a glucose oxidase method (A) and insulin serum levels, determined by an ELISA kit $(\mathbf{B})$. Results are reported as mean \pm SEM. ${ }^{*} P<0.05$ vs other groups.

Fig. 2. Effect of rOPG injections on pancreas islet morphology. Representative histological sections of pancreas (microscope magnification 20X); specimens from control (CONT), OPG injected (OPG) and OPG injected treated with ramipril (OPG-R) mice. Dense immunostaining for insulin (upper panel) in CONT islets (A) and diffuse staining in OPG islets (B). Increased staining density after blockade of the RAS with ramipril $(\mathbf{C})$. Staining for picrosirius red (middle panel) and for F4/80 (lower panel) in islets from CONT $(\mathbf{D}, \mathbf{G})$, OPG $(\mathbf{E}, \mathbf{H})$ and OPG-R $(\mathbf{F}, \mathbf{I})$ mice.

Fig. 3. Effect of in vivo injections of rOPG on beta cell apoptosis. Beta cell apoptosis is expressed as the average number of TUNEL positive cells per insula in control (CONT), OPG injected (OPG), control treated with ramipril (CONT-R) and OPG injected treated with ramipril (OPG-R) C57BL/6J mice. Bars indicate mean \pm SEM ( $\mathrm{n}=6$ animals per group). ${ }^{*} P<0.01$ vs other groups.

Fig. 4. Effect of rOPG treatment on MCP-1, VCAM-1, TGF- $\beta$ and CTGF RNA levels in pancreas. Gene expression analysis was assessed by quantitative RT-PCR on whole pancreas extracts of control (CONT), OPG injected (OPG), control treated with ramipril (CONT-R) and OPG injected treated with ramipril (OPG-R) C57BL/6J mice. Gene expression is expressed relative to the CONT group, which was arbitrarily designated as 1 . In panel A, mRNA expression of monocyte chemotactic protein-1 (MCP-1) $\left({ }^{*} P<0.05\right.$ vs other groups), and vascular adhesion molecule-1 
(VCAM-1) ( ${ }^{*} P<0.05$ vs other groups). In panel $\mathbf{B}$, mRNA expression of transforming growth factor- $\beta$ (TGF- $\beta)\left({ }^{*} P<0.05\right.$ vs other groups), and connective tissue growth factor (CTGF) $\left({ }^{*} P<0.05\right.$ vs CONT and OPG groups; ${ }^{\dagger} P<0.0001$ vs CONT-R group). Bars indicate mean \pm SEM (n=6 animals per group). 
Table 1. TaqMan Primers and Probe Sequences used for real-time RT-PCR in pancreas extracts

\begin{tabular}{|c|c|}
\hline Name & Sequence \\
\hline ACE probe & FAM-5'-CAACAAGACTGCCACCTGCTGGTCC-3'-TAMRA \\
\hline ACE primer $F$ & 5'-CAGAATCTACTCCACTGGCAAGGT-3' \\
\hline ACE primer $R$ & 5'-TCGTGAGGAAGCCAGGATGT-3' \\
\hline AT1 receptor probe & FAM-5'-TACCAGTGGCCCTTCGGCAATCA-3'-TAMRA \\
\hline AT1 receptor primer $F$ & 5'-GGGCAGTTTATACCGCTATGGA-3' \\
\hline AT1 receptor primer $\mathrm{R}$ & 5'-TGGCCGAAGCGATCTTACAT-3' \\
\hline CTGF probe & FAM-5'-ACTGCCTGGTCCAGAC-MGB \\
\hline CTGF primer $\mathrm{F}$ & 5'-GCTGCCTACCGACTGGAAGA-3' \\
\hline CTGF primer $\mathrm{R}$ & 5'-CTTAGAACAGGCGCTCCACTCT-3' \\
\hline VCAM-1 probe & FAM-5'-CGGCATCCTGCAGCTGTGCCT-3'-TAMRA \\
\hline VCAM-1 primer $\mathrm{F}$ & 5'-AAGTCTGTGGATGGCTCGTACA-3' \\
\hline VCAM-1 primer $\mathrm{R}$ & 5'-TCAGTCTTAGATTCACACTCGTATATGC-3' \\
\hline MCP-1 probe & FAM-5'-TCCCTGTCATGCTTCTGGGCCTGT-3'-TAMRA \\
\hline MCP-1 primer $\mathrm{F}$ & 5'-СТТССТССАCСАCCATGCA-3' \\
\hline MCP-1 primer $\mathrm{R}$ & 5'-CCAGCCGGCAACTGTGA-3' \\
\hline TGF- $\beta$ probe & FAM-5'-AAAGCCCTGTATTCCGT-MGB \\
\hline TGF- $\beta$ primer $F$ & 5'-GCAGTGGCTGAACCAAGGA-3' \\
\hline TGF- $\beta$ primer $\mathrm{R}$ & 5'-GCAGTGAGCGCTGAATCGA-3' \\
\hline
\end{tabular}

FAM=6-carboxyfluorescein, TAMRA (quencher)=6-carboxy-tetramethylrhodamine, MGB=minor groove binder 
Table 2. Characteristics of the mice at the end of the study

\begin{tabular}{lcccc}
\hline Parameters & CONT & OPG & CONT-R & OPG-R \\
& $(\mathrm{n}=10)$ & $(\mathrm{n}=10)$ & $(\mathrm{n}=10)$ & $(\mathrm{n}=10)$ \\
\hline Body weight $(\mathrm{g})$ & $29.5 \pm 1.5$ & $31.2 \pm 1.3$ & $30.1 \pm 1.6$ & $28.5 \pm 2.0$ \\
SBP $(\mathrm{mmHg})$ & $95 \pm 2$ & $98 \pm 3$ & $80 \pm 2^{\mathrm{a}}$ & $83 \pm 2^{\mathrm{a}}$ \\
AUC $(\mu \mathrm{g} / \mathrm{L} / \mathrm{min})$ & $150 \pm 20$ & $90 \pm 15^{\mathrm{b}}$ & $145 \pm 18$ & $143 \pm 17$ \\
\hline
\end{tabular}

Data are expressed as mean \pm SEM.

SBP, systolic blood pressure; AUC, area under insulin curve; CONT, control mice; OPG, mice injected with recombinant human OPG; CONT-R, mice injected with vehicle and treated with ramipril; OPG-R, mice injected with OPG and treated with ramipril. ${ }^{\mathrm{a}} P<0.05$ vs CONT and OPG groups; ${ }^{\mathrm{b}} P<0.01$ vs other groups 
Table 3. Intra- and peri-islet fibrosis and macrophages infiltration

Picrosirius

$\mathrm{F} 4 / 80$

\begin{tabular}{|c|c|c|c|c|}
\hline & Intra-islet & Peri-islet & Intra-islet & Peri-islet \\
\hline CONT & $3.7 \pm 0.3$ & $12.4 \pm 0.9$ & $0.019 \pm 0.005$ & $0.163 \pm 0.036$ \\
\hline OPG & $6.3 \pm 0.7^{\mathrm{a}}$ & $16.6 \pm 1.2^{\mathrm{a}}$ & $0.098 \pm 0.01^{\mathrm{a}}$ & $0.406 \pm 0.079^{\mathrm{a}}$ \\
\hline CONT-R & $3.0 \pm 0.4$ & $11.3 \pm 0.3$ & $0.013 \pm 0.009$ & $0.197 \pm 0.086$ \\
\hline OPG-R & $3.9 \pm 0.1$ & $13.5 \pm 0.8$ & $0.017 \pm 0.007$ & $0.132 \pm 0.038$ \\
\hline \multicolumn{5}{|c|}{$\begin{array}{l}\text { Data for picrosirius are expressed as proportional area (\%) of each islet (intra-) or of isle } \\
\text { boundaries (peri-) occupied by positive staining, shown as mean } \pm \text { SEM. Data for F4/80 are } \\
\text { expressed as average of the number of cells staining positive in insular- or peri-insular level } \pm \mathrm{SEM}\end{array}$} \\
\hline
\end{tabular}


Table 4. Expression of components of the RAS as quantified by immunohistochemistry and realtime RT-PCR
ACE
AT1 receptor

Immunohistochemistry

CONT

$8.0 \pm 1.7$

$2.7 \pm 1.0$

OPG

$16.1 \pm 3.2^{\mathrm{a}}$

$5.5 \pm 0.6^{\mathrm{a}}$

CONT-T

$6.3 \pm 2.2$

$2.9 \pm 0.8$

OPG-R

$8.7 \pm 1.1$

$3.1 \pm 0.5$

Real-time RT-PCR

CONT

$1.0 \pm 0.6$

$1.0 \pm 0.2$

OPG

$8.7 \pm 2.8^{b}$

$2.2 \pm 0.4^{\mathrm{a}}$

CONT-R

$$
0.6 \pm 0.1
$$

$1.0 \pm 0.2$

OPG-R

$$
0.7 \pm 0.3
$$

$1.1 \pm 0.3$

Data are proportional area (\%) of each islet occupied by positive staining for specific islet proteins, shown as mean \pm SEM (for immunohistochemistry); and data are results from gene expression study presented as a ratio compared with CONT, shown as mean \pm SEM (for real-time RT-PCR). ${ }^{\mathrm{a}} P<0.05$ vs other groups; ${ }^{\mathrm{b}} P<0.0001$ vs other groups. 
A $\rightarrow$ CONT $\rightarrow$ OPG $\rightarrow$ CONT-R $\leadsto$ OPG-R

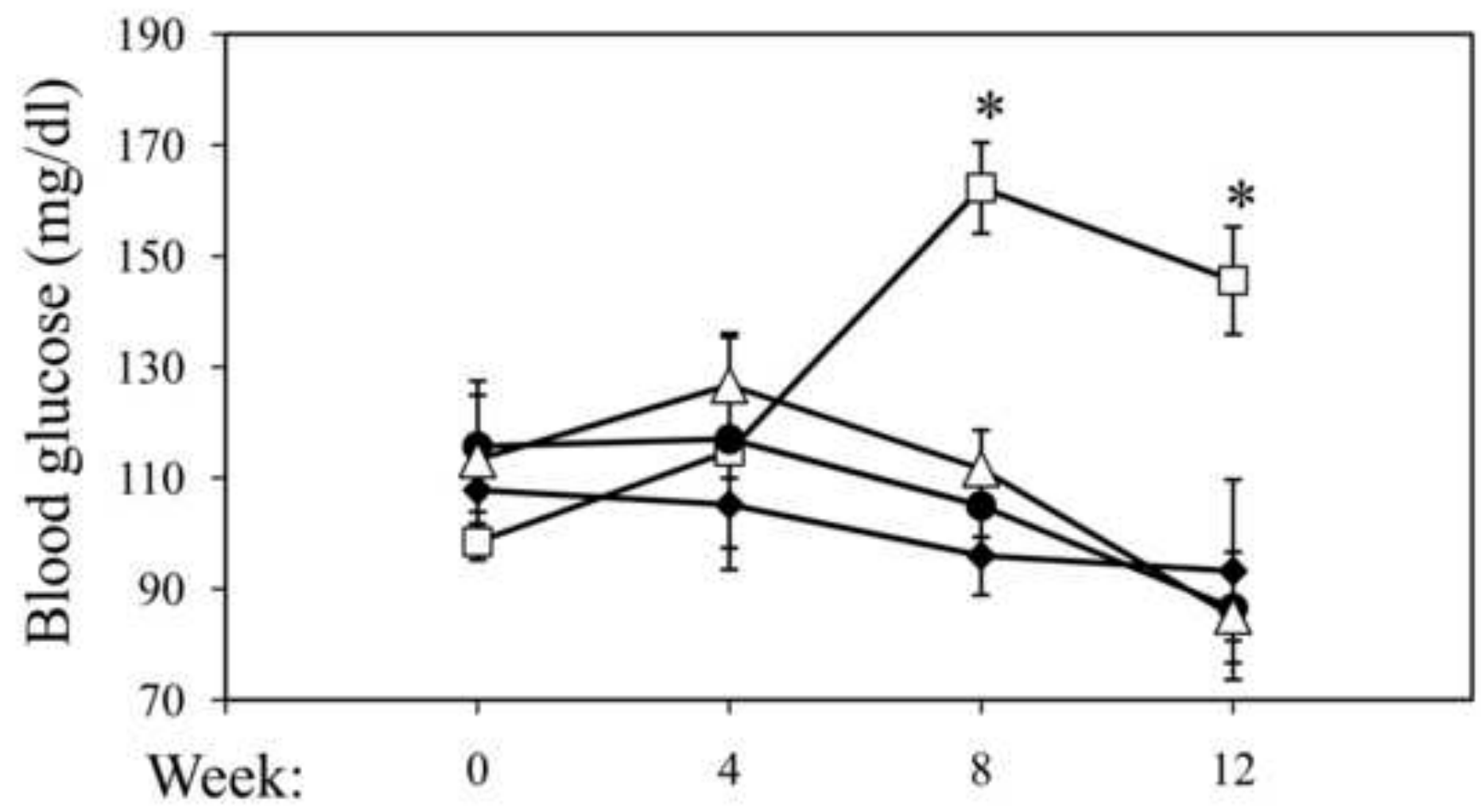

B

$\rightarrow$ CONT $\rightarrow$-OPG $\bullet$ CONT-R $\leadsto$ OPG-R

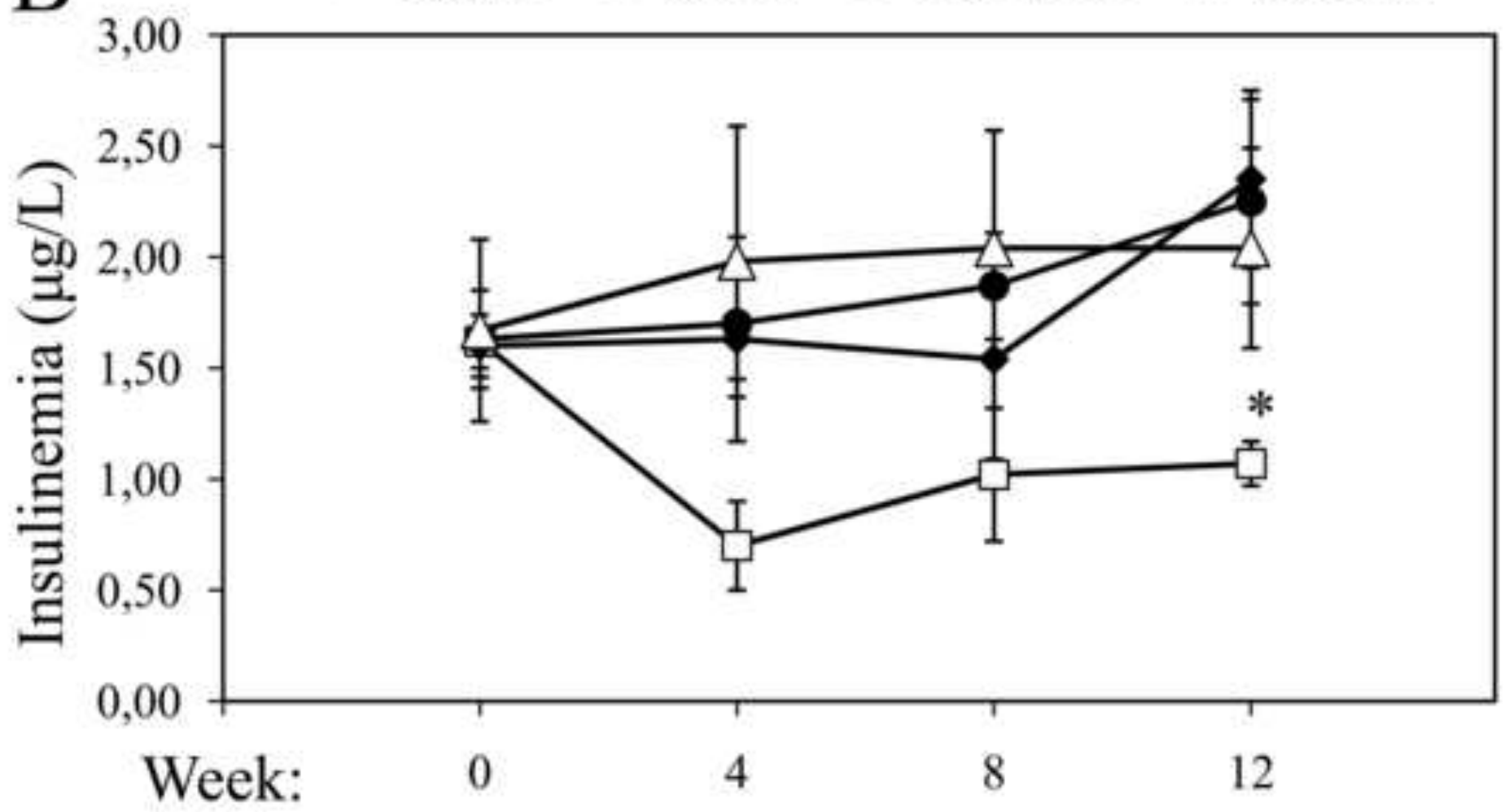



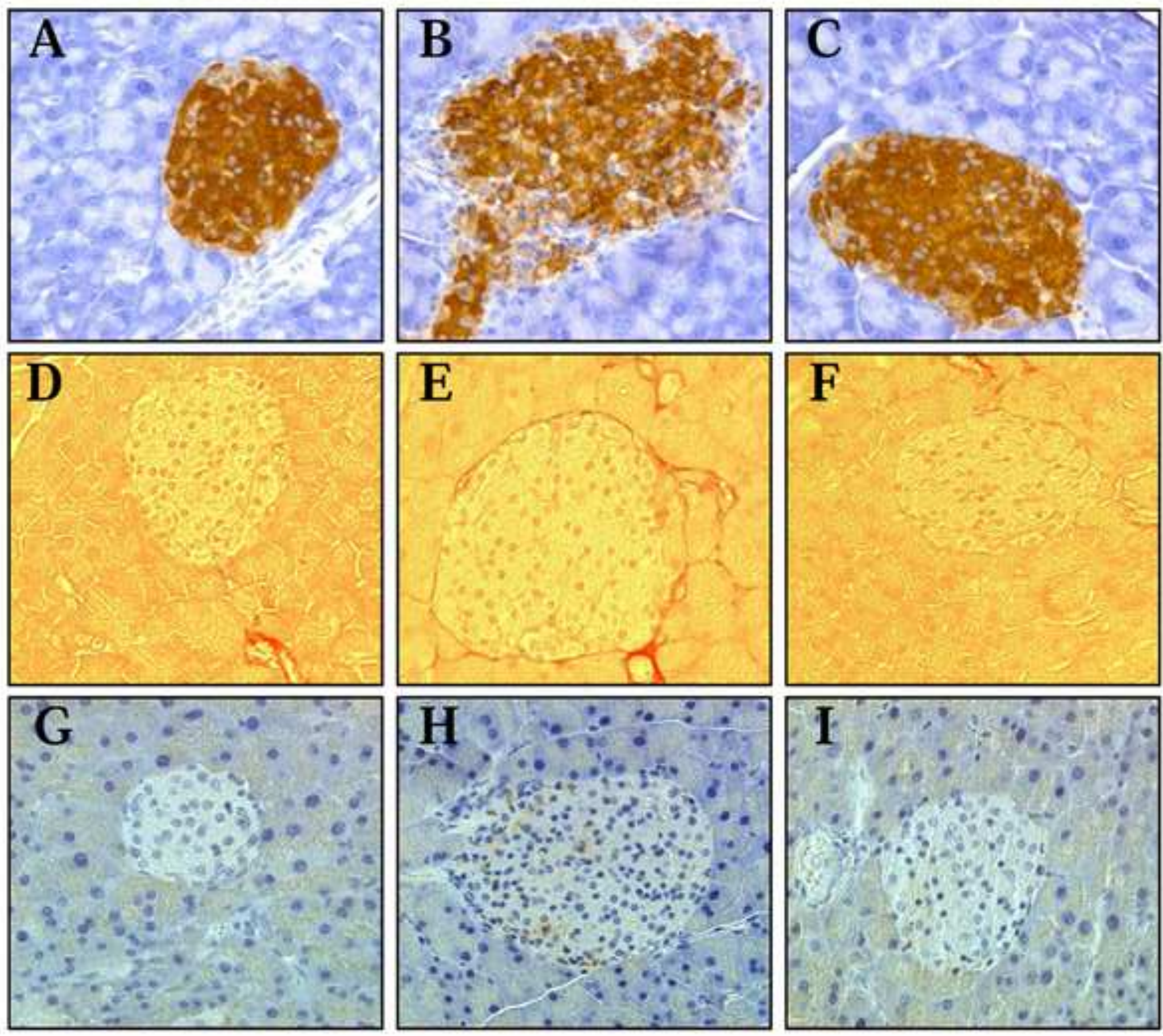

rage 31 or 33 


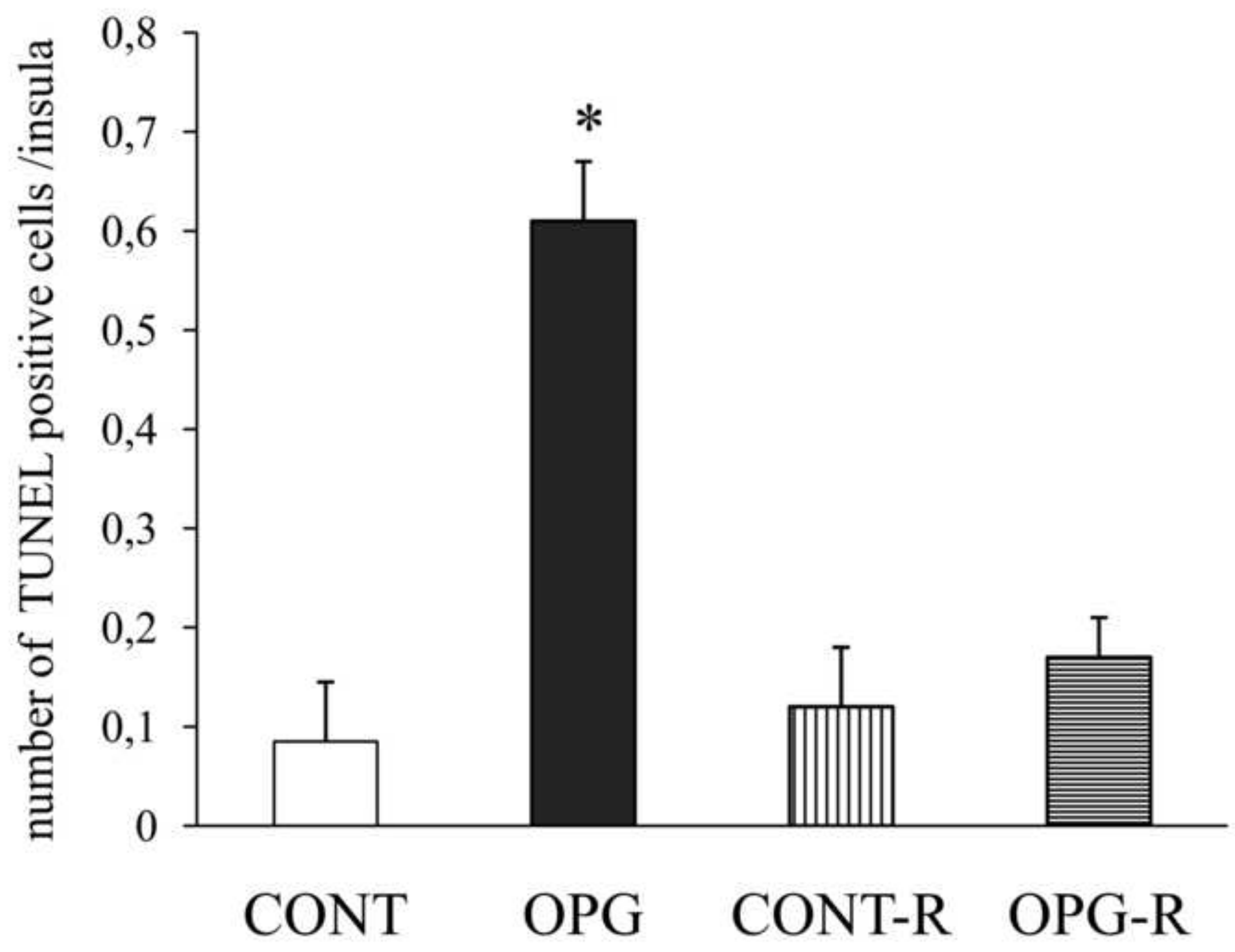

rage 32 or 33 
A $\square$ CONT $\square$ OPG $\square$ CONT-R 目OPG-R

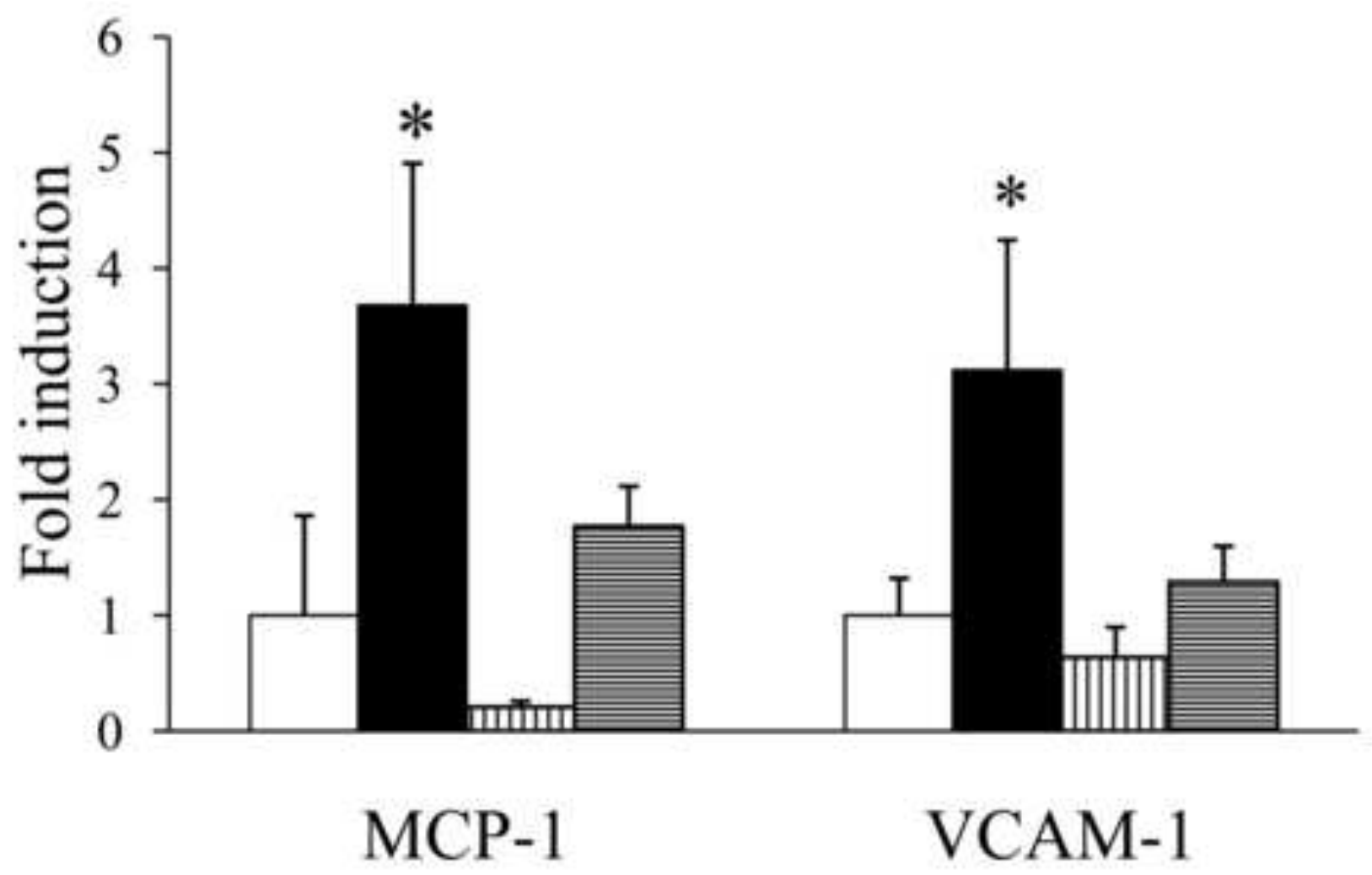

B

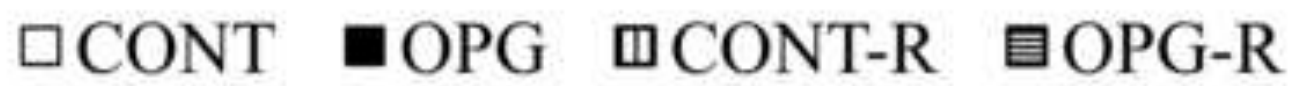

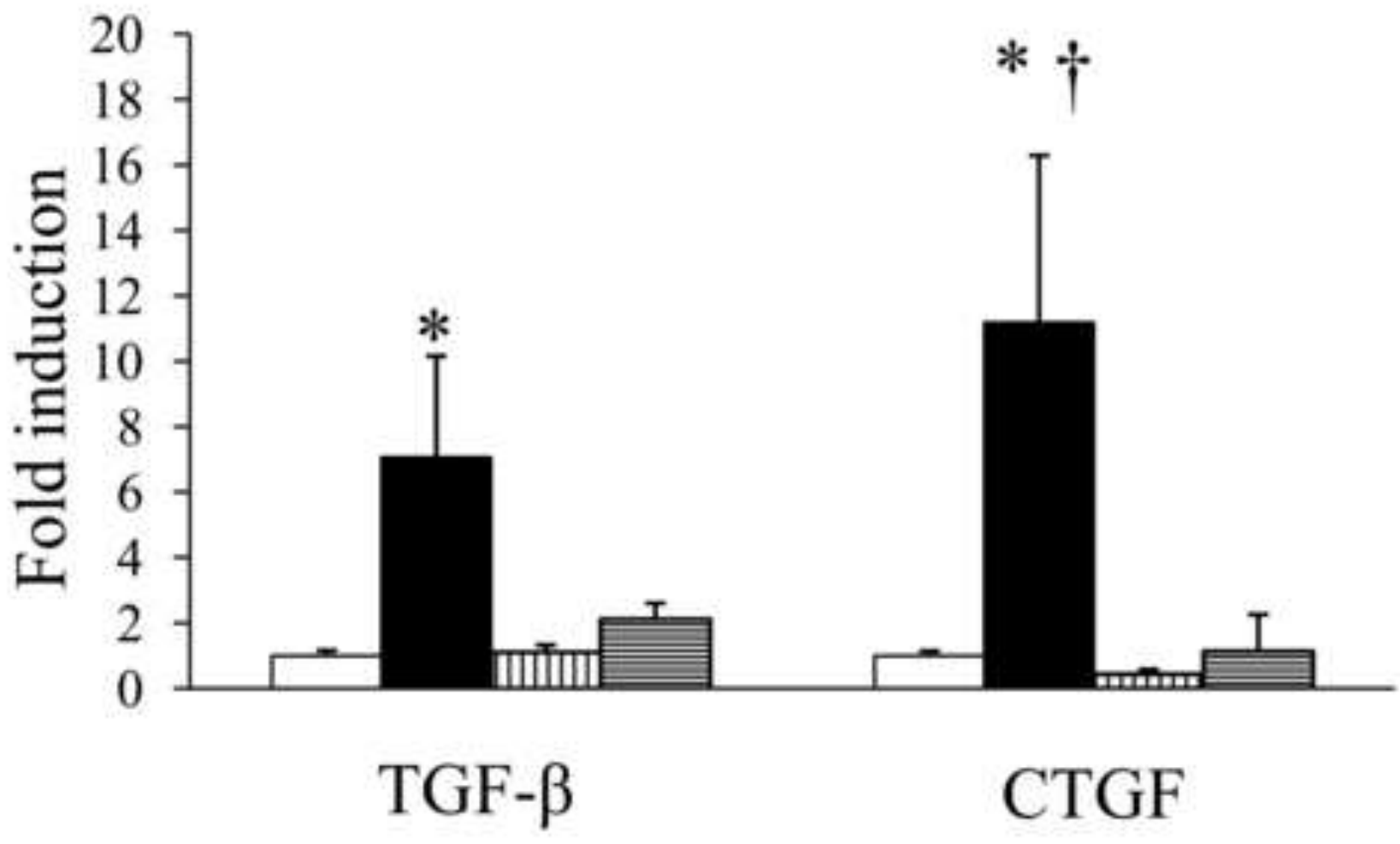

